\title{
Premarital Romantic Partnerships: Attitudes and Sexual Experiences of Youth in Delhi, India
}

\begin{abstract}
CONTEXT: Despite restrictive social norms, there is increasing evidence that youth in India engage in premarital romantic and sexual partnerships. However, information on how they initiate and build these relationships is scarce, even though it is vital for addressing the needs of young people.
\end{abstract}

METHODS: Attitudes toward and behavior within romantic partnerships were examined using data collected in 2004 from unmarried youth (583 males and 475 females, aged 15-19) living in economically disadvantaged neighborhoods in Delhi, India. Associations between specific attitudes or behaviors and age, gender and sexual experience were determined using Fisher's exact tests.

RESULTS: Sixty-two percent of males and 53\% of females reported that someone of the opposite sex had expressed an interest in them; $86 \%$ of males and $63 \%$ of females reported feeling good about it. In addition, $67 \%$ of males and $47 \%$ of females reported that they liked someone from the opposite sex. Compared with females, males were more likely to seek information about the person they were interested in (76\% vs. 61\%), and to engage in heterosexual premarital sex (32\% vs.6\%). Females were less likely than males to report that it is okay to engage in premarital sex if the male and female love one another (14\% vs. 33\%). For both males and females, television and films were the most popular source of information on issues related to sexual health.

CONCLUSIONS: Gender disparities in premarital romantic partnership formation and the experience of sexual relations make a strong case for sexuality education programs tailored to the different experiences and circumstances of young men and women.

International Perspectives on Sexual and Reproductive Health, 2009, 35(2):97-104
By Jaya and

Michelle J. Hindin

Jaya is program officer, Adolescent Reproductive and Sexual Health, United Nations Population Fund, New Delhi, India. Michelle J. Hindin is associate professor, Department of Population, Family and Reproductive Health, Johns Hopkins Bloomberg School of Public Health, Baltimore, MD, USA.
Research conducted by the World Health Organization suggests that much of the sexual activity that begins in adolescence is high-risk, unsafe and oftentimes nonconsensual. ${ }^{1}$ A majority of young people do not have correct information on the use of contraceptives or the prevention of pregnancy and STIs, and youth-friendly reproductive health services are not readily available. Moreover, in many cultures, expressed social norms condemn premarital sex, especially for women, and there are large gender-based differences in sexual conduct and in the ability to negotiate sexual activity and contraceptive use. ${ }^{1}$

Research also suggests that, for adolescents, being in school and having high educational aspirations, living with both parents and having high self-efficacy to refuse unsafe or unwanted sex are protective against risky premarital sexual relations. ${ }^{2}$ On the other hand, poor academic performance; abuse of substances, such as drugs, alcohol and tobacco; access to pornographic films and other X-rated materials; having peers who are sexually active; family instability; and being part of the workforce, especially for males, are inversely associated with lower-risk sexual activities. ${ }^{2}$ Globally, there is increasing consensus that comprehensive behavioral interventions must take account of social context and aim to modify social norms that support uptake and maintenance of behavior change. ${ }^{3}$
In India, globalization, urbanization, rapid economic growth and the extensive reach of media have vastly changed the realities of young people in just a generation. Young people are exposed to new ideas and are better informed about their rights and responsibilities. ${ }^{4}$ Urbanization has led to increased opportunities for education for young people; simultaneously, it has eased the transition from traditional extended families to nuclear families with minimal community support systems. The declining age at puberty and the increasing age at marriage have created a growing window of opportunity in which young people may engage in premarital romantic and sexual relationships. $^{5}$

All of these factors have clear implications for adolescents and their sexual behavior. However, social norms have not kept pace with changing circumstances. In India a double standard for females and males prevails. Young people are confronted with marked gender disparities in the social norms governing their sexual behavior. ${ }^{6-9}$ Young women are subject to strict supervision and are commonly prohibited from socializing with males outside their families. ${ }^{6}$ In contrast, young men, who enjoy more freedom, find it easier to explore sex before marriage, in cluding the services of commercial sex workers. ${ }^{6,10}$ The youth themselves are aware of these double standards. 
Young men often use coercive behaviors, ranging from derogatory comments to forced sexual intercourse, to demonstrate their dominance in heterosexual interactions or relationships. ${ }^{11}$ Gender power imbalances encourage secrecy, and inhibit negotiation between partners. ${ }^{12}$ The hint of a premarital relationship can precipitate parents into pressuring a young woman to marry a man not of her choice; as a result, young women fear disclosure of their sexual activity. 6,7

Parents often believe that strict supervision of children inhibits their formation of romantic or sexual partnerships; findings from a 2007 survey of 15-24-year-olds in Pune district in Maharashtra indicate that this belief may be unfounded. ${ }^{5}$ Evidence suggests that despite a conservative environment that disapproves of interactions among adolescent males and females, there are opportunities for social mixing, and young people have devised ways of developing romantic partnerships with the opposite sex. ${ }^{5-7,10,13,14(\text { pp. } 150-151)}$

In view of these realities, fewer females than males engage in premarital sexual behaviors. In the most recent National Family Health Survey (2005-2006), 9\% of young men aged 15-19 and 13\% aged 20-24 reported having had premarital sex. In the same survey, $1 \%$ of females in each of those age-groups reported premarital sex. ${ }^{15}$ A 2008 community-based survey of 15-24-year-olds conducted in Maharashtra found that $11 \%$ of urban males and $21 \%$ of rural males reported premarital sexual intercourse, compared with $1 \%$ of urban females and 3\% of rural females. ${ }^{14(p .167)}$ In the 2007 study conducted in Pune district, $36 \%$ of young men and $31 \%$ of young women in urban settings reported either receiving or initiating a proposal for romantic partnership before marriage. ${ }^{5}$ And according to another study conducted in 22 schools and colleges in Patna, 28\% of males and 12\% of females reported having experienced any physical intimacy, and 23\% of males and 9\% of females reported having experienced kissing, touching or sexual intercourse. ${ }^{16}$ However, there is some evidence that females tend to underreport sexual behaviors, whereas males tend to overreport them. ${ }^{12,17}$

For males, more freedom in the absence of reliable sources of information on safe sexual practices implies an increased probability of acquiring STIs, including HIV. Moreover, young men who have premarital sex put the

*For the purpose of this study, "romantic partnership" implies association that is based on interest in the opposite sex. Given the context, romantic partnership does not necessarily mean a friendship or sexual relationship between the partners; however, it could lead to a friendship or a sexual relationship.

tIndian Rs 3,000=US\$70.

‡These were interviewer-administered and were supported by severa audiovisual aids, such as a five-segment audio drama that recreated situations from the lives of the respondents. These interviews also included interviewer-guided, anonymous individual sheets on which participants responded to questions on their sexual behaviors.

$\S$ The details on the sample size, methods and results from the parent study are available elsewhere (source: Jaya, Hindin MJ and Ahmed S, Differences in young people's reports of sexual behaviors according to interview methodology: a randomized trial in India, American Journal of Public Health, 2008, 98(1):169-174). young women they marry at risk of acquiring STIs, even if the young women did not engage in premarital sex themselves. $^{18}$

It is clear that initiatives that aim to improve the sexual health of young people in India are needed. An increasing number of studies ${ }^{4-6,13,16,19,20}$ have explored sexual experiences of youth in different settings in India. However, more information is needed so that interventions that address the sexual health needs of youth in a culturally relevant and gender-sensitive manner can be developed. The fact that 10-24-year-olds account for 30\% of India's population (327 million individuals) $)^{21}$ and $31 \%$ of the AIDS cases in the country ${ }^{22}$ has added urgency to addressing the reproductive and sexual health needs of this agegroup.

Using a gender lens, this study explores how males and females indicate interest in one another, elicits their opinions on premarital sex and examines how they engage in sexual behaviors in a social context that is not supportive of premarital romantic or sexual relationships. The study further explores patterns in romantic partnerships* and attitudes toward sex by age and sexual experiences of respondents.

\section{METHODS Study Design}

In collaboration with Samudayik Shakti, an organization that works on issues related to domestic violence, the study was conducted in economically disadvantaged neighborhoods of Dakshin Puri, Delhi, India. These neighborhoods are home to low-income families (a substantial proportion of families live on a monthly family income of less than Rs 3,000. ${ }^{\dagger}$ A majority of the residents work in the informal sector and are engaged in low-paying or unskilled jobs, such as those in factories, warehouses or construction, or provide domestic help in affluent neighborhoods.

The study sample for this analysis is derived from a randomized crossover trial that compared face-to-face interviews (the standard interview methodology) to audio computer-assisted self-interviews and culturally relevant interactive interviews ${ }^{\ddagger}$ to determine whether adolescents' reports about their sexual experiences changed as a result of the interview methodology. A household enumeration in November 2003 and March-April 2004 preceded the trial. We started household enumeration in one slum and continued in contiguous slums until we reached the required number of adolescents for the parent study. All unmarried 15-19-year-olds living in four economically disadvantaged neighborhoods of Dakshin Puri were eligible to participate. ${ }^{\S}$

The interviewers, the majority of whom were aged 18-24, were identified locally. They were matched to respondents by sex. They were trained to be nonjudgmental, and the importance of maintaining participant confidentiality was stressed. The study was approved by the Johns Hopkins Bloomberg School of Public Health Institutional Review Board and a local institutional review 
board in India. Parental consent was obtained before approaching the adolescents; consent was obtained from the adolescents just before enrolling them in the trial.

Structured interviews with closed-ended questions were used to elicit responses on a range of issues related to sexuality and sexual behaviors. For example, respondents were asked such questions as "Should boys and girls interact with one another?" and "Did any girl/boy ever express interest in you?"

Questions were asked in the local language (Hindi). On average, the administration of the full protocol lasted 90-120 minutes. Complete privacy was ensured, and we did not record names of participants. Missing data were minimal (0.2-1\%). Data were checked daily and entered into Microsoft Access.

At the end of the interviews, every participant was given a metal box containing snacks (total cost not exceeding US\$.60). All the participants were provided with the address of an organization and telephone helpline where they could seek free counseling on sexual health issues. With the respondents' permission, our collaborating organization, Samudayik Shakti, was informed of cases of nonconsensual sexual experiences.

\section{Statistical and Analytical Techniques}

As the parent study required every participant to be interviewed both face-to-face and in another interview methodology, we had two responses from every participant. We generated dichotomous variables by coding the respondents as having expressed a perception or engaged in a behavior they reported on either one or both of the interview modes.

We conducted the analysis in Stata version 9. As the absolute number in some cells was fewer than five, we used Fisher's exact tests to compare proportions for outcome variables with categorical responses. ${ }^{23}$ First, we explored the association between specific attitudes or behaviors and the gender of the respondent using Fisher's exact tests. Further, we explored differences in behaviors between adolescent men and women, stratified by their age-group and sexual experience. In these analyses, age was coded as a dichotomous variable, i.e., 15-17 and 18-19 years old.

\begin{tabular}{|c|c|c|}
\hline Characteristic & $\begin{array}{l}\text { Male } \\
(\mathrm{N}=583)\end{array}$ & $\begin{array}{l}\text { Female } \\
(\mathrm{N}=475)\end{array}$ \\
\hline \multicolumn{3}{|l|}{$\operatorname{Age}^{* * *}$} \\
\hline $15-17$ & 61 & 79 \\
\hline $18-19$ & 39 & 21 \\
\hline Currently in school & 32 & 33 \\
\hline Ever worked ${ }^{* * *}$ & 73 & 54 \\
\hline \multicolumn{3}{|l|}{ Family income ${ }^{* * *}$} \\
\hline$\leq$ Rs 3000 & 36 & 56 \\
\hline$>$ Rs 3000 & 64 & 44 \\
\hline \multicolumn{3}{|l|}{ Religion } \\
\hline Hindu & 73 & 75 \\
\hline Other & 27 & 25 \\
\hline $\begin{array}{l}\text { Ever had sex with someone } \\
\text { of the opposite sex }\end{array}$ & 32 & 6 \\
\hline $\begin{array}{l}\text { Ever had sex with someone } \\
\text { of the same sex }\end{array}$ & 10 & 2 \\
\hline
\end{tabular}

The variable on sexual experience was also a dichotomous variable, i.e., having reported a sexual relationship and having not reported one.

\section{RESULTS}

The final sample for analysis included 583 males and 475 females. Females in the study sample were younger than males, with $79 \%$ of females and $61 \%$ of males aged $15-17$, suggesting that in these areas, females tend to get married at a younger age than males (Table 1). Only one-third of respondents were in school at the time of the survey. Nearly three-fourths of the males and half of the females in the study sample had ever been in the workforce. Thirty-six percent of males and $56 \%$ of females were from families with a monthly income of Rs 3,000 or less. The majority of the respondents were Hindu. Thirty-two percent of males and $6 \%$ of females reported having had sex with someone of the opposite sex; $10 \%$ of males and $2 \%$ of females re-

TABLE 2. Percentage of unmarried youth reporting selected premarital romantic behaviors, by age and sexual experience, according to gender

\begin{tabular}{|c|c|c|c|c|c|c|c|c|c|c|}
\hline \multirow[t]{2}{*}{ Behavior/experience } & \multicolumn{2}{|l|}{ All } & \multicolumn{2}{|l|}{$15-17$} & \multicolumn{2}{|l|}{$18-19$} & \multicolumn{2}{|c|}{$\begin{array}{l}\text { No sexual } \\
\text { relationship }\end{array}$} & \multicolumn{2}{|c|}{$\begin{array}{l}\text { Sexual } \\
\text { relationship }\end{array}$} \\
\hline & $\begin{array}{l}\text { Male } \\
(\mathrm{N}=583)\end{array}$ & $\begin{array}{l}\text { Female } \\
(\mathrm{N}=475)\end{array}$ & $\begin{array}{l}\text { Male } \\
(\mathrm{N}=356)\end{array}$ & $\begin{array}{l}\text { Female } \\
(\mathrm{N}=376)\end{array}$ & $\begin{array}{l}\text { Male } \\
(\mathrm{N}=227)\end{array}$ & $\begin{array}{l}\text { Female } \\
(\mathrm{N}=99)\end{array}$ & $\begin{array}{l}\text { Male } \\
(\mathrm{N}=382)\end{array}$ & $\begin{array}{l}\text { Female } \\
(\mathrm{N}=441)\end{array}$ & $\begin{array}{l}\text { Male } \\
(\mathrm{N}=201)\end{array}$ & $\begin{array}{l}\text { Female } \\
(\mathrm{N}=34)\end{array}$ \\
\hline Interact with opposite sex & 51 & 57 & 54 & 48 & 57 & 67 & 38 & $56^{* * *}$ & 77 & 68 \\
\hline Have friends of the opposite sex & 62 & $40^{* * *}$ & 56 & $38^{* * *}$ & 71 & $45^{* * *}$ & 48 & $37^{* * *}$ & 88 & 74 \\
\hline $\begin{array}{l}\text { Peers starting to get interested } \\
\text { in each other }\end{array}$ & 94 & $87^{* * *}$ & 92 & $85^{* *}$ & 98 & $93^{*}$ & 91 & $86^{*}$ & 99 & 100 \\
\hline $\begin{array}{l}\text { Someone of the opposite sex } \\
\text { expressed interest in respondent }\end{array}$ & 62 & $53^{* *}$ & 53 & 51 & 74 & $58^{* *}$ & 50 & 51 & 84 & 71 \\
\hline Ever liked someone of the opposite sex & 67 & $47^{* * *}$ & 61 & $46^{* * *}$ & 75 & $50 * * *$ & 56 & $45^{* * *}$ & 87 & 77 \\
\hline
\end{tabular}

*Gender differences are significant at $p \leq .05 .{ }^{* *}$ Gender differences are significant at $p \leq .01 .{ }^{* * *}$ Gender differences are significant at $p \leq .001$. Note: $p$ values determined with Fisher's exact test. 
FIGURE 1. Among unmarried youth who reported interest from the opposite sex, percentage reporting selected reactions, by gender

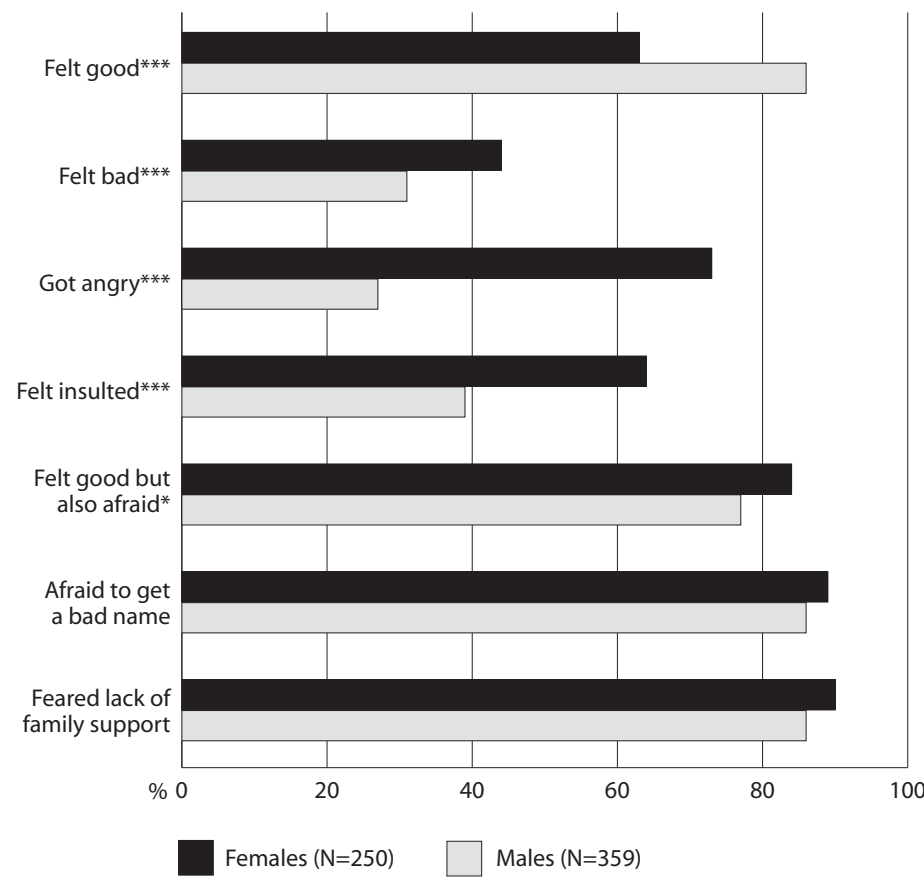

${ }^{*}$ Gender differences are significant at $p<.05 .{ }^{* * *}$ Gender differences are significant at $p<.001$. Note: Multiple responses were allowed.

FIGURE 2. Among unmarried youth who reported interest in a member of the opposite sex, percentage reporting selected methods of pursuing interest, by gender

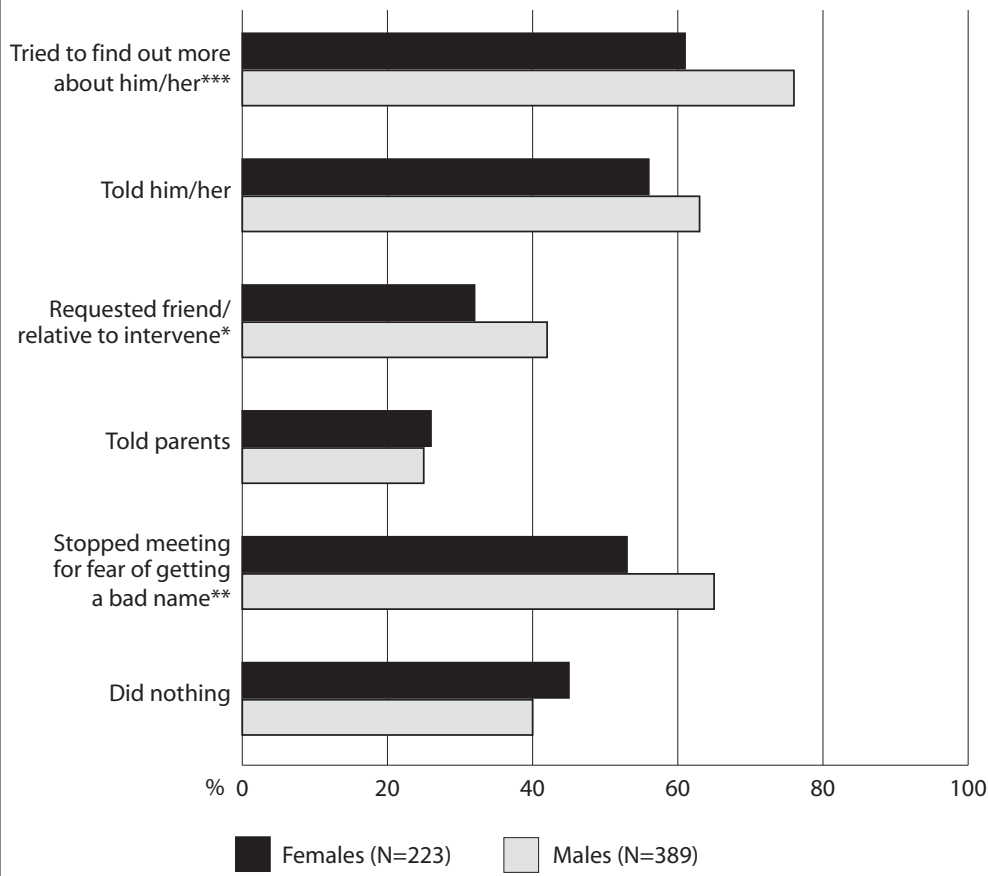

${ }^{*}$ Gender differences are significant at $p<.05 .{ }^{* *}$ Gender differences are significant at $p<.01 .{ }^{* * *}$ Gender differences are significant at $\mathrm{p}<.001$. Note: Multiple responses were allowed. ported a sexual relationship with someone of the same sex. All differences between genders were significant except those for being in school and religion. Among those who reported a heterosexual sexual relationship, $82 \%$ of males and $62 \%$ of females reported feeling good after the experience; $31 \%$ of males and $48 \%$ of females reported feeling bad after the experience (not shown). It is interesting to note that $13 \%$ of males and $10 \%$ of females reported both negative and positive feelings after a sexual experience; this may reflect the ambivalence associated with premarital sex in settings with a strong social taboo against it.

\section{Interactions with the Opposite Sex}

Overall, males reported more interactions with the opposite sex than females (Table 2, page 99). Males were more likely to report having friends of the opposite sex (62\% vs. 40\%) and to acknowledge that both males and females in their age-group had begun to be interested in one another (94\% vs. $87 \%$ ). In comparison with females, a larger proportion of males reported that someone of the opposite sex had expressed interest in them (62\% vs. 53\%), and that they had ever liked someone of the opposite sex (67\% vs. 47\%).

The comparisons between younger and older adolescents show patterns similar to the overall findings. In comparison with 15-17-year-old females, males in this agegroup more often reported having friends of the opposite sex (56\% vs. 38\%), acknowledged that young people in their age-group had begun to be interested in one another ( $92 \%$ vs. $85 \%$ ) and reported that they had ever liked someone of the opposite sex (61\% vs. 46\%). Among the older adolescents, the pattern of significant differences was the same as in the overall sample.

In comparing adolescents who reported having had a sexual relationship with those who had not, we see another pattern of gender differences. Among respondents who had not had a sexual relationship, females were more likely than males to report interactions with the opposite sex (56\% vs. 38\%). However, males who had not had a sexual relationship more often reported having friends of the opposite sex (48\% vs. 37\%) and having ever liked someone of the opposite sex ( $56 \%$ vs. $45 \%$ ) than did their female counterparts. When comparing males and females who reported a sexual relationship, we found no significant gender differences in the reported behaviors.

\section{Reactions to the Opposite Sex}

The 359 males and 250 females who reported that someone of the opposite sex had expressed an interest in them were asked to report their reactions (Figure 1). Overall, in comparison with males, females were more likely to report negative reactions. While $63 \%$ of females and $86 \%$ of males reported that the interest made them feel good, $44 \%$ of females and $31 \%$ of males reported that it made them feel bad. Seventy-three percent of females, compared with $27 \%$ of males, reported that they became angry when someone of the opposite sex expressed an interest in them; $64 \%$ of females felt insulted, compared with 39\% of 
males. A majority of the respondents expressed ambivalence- $84 \%$ of females and $77 \%$ of males reported that although they felt good when someone of the opposite sex expressed an interest in them, they were also afraid.

Among the 389 males and 223 females who reported that they were interested in someone of the opposite sex, $76 \%$ of males and $61 \%$ of females reported that they tried to find out more about the person they liked (Figure 2). Some $32 \%$ of females and $42 \%$ of males asked a relative or a friend to intervene on their behalf. Interestingly, $65 \%$ of males and $53 \%$ of females stopped meeting the person they liked because they feared getting a "bad name." In addition, $45 \%$ of females and $40 \%$ of males reported that although they liked someone of the opposite sex, they did nothing to pursue their interest; the difference between the sexes on this variable was not significant.

Among males and females who reported an interest in someone of the opposite sex, $57 \%$ of males and $68 \%$ females reported that they had spoken to the person they liked on a few occasions (Figure 3). Thirty-nine percent of males and $15 \%$ of females reported that they had ever touched one another, indicating that physical contact is still a taboo, especially for the females. Twenty-five percent of males and $16 \%$ of females considered their relationship a casual one; $51 \%$ of males, in comparison with $40 \%$ of females, said that they would like to marry the person they were interested in.

\section{Attitudes Toward Premarital Sex}

Overall, females had more conservative attitudes than males (Table 3). Females were more likely than males to agree that only married people should have a sexual relationship (96\% vs. 92\%) and less likely than males to agree that if a male and female love one another it is okay for them to have a sexual relationship (14\% vs. $33 \%$ ), that fe-
FIGURE 3. Among those reporting interest in a member of the opposite sex, percentage reporting selected characteristics of their relationship, by gender

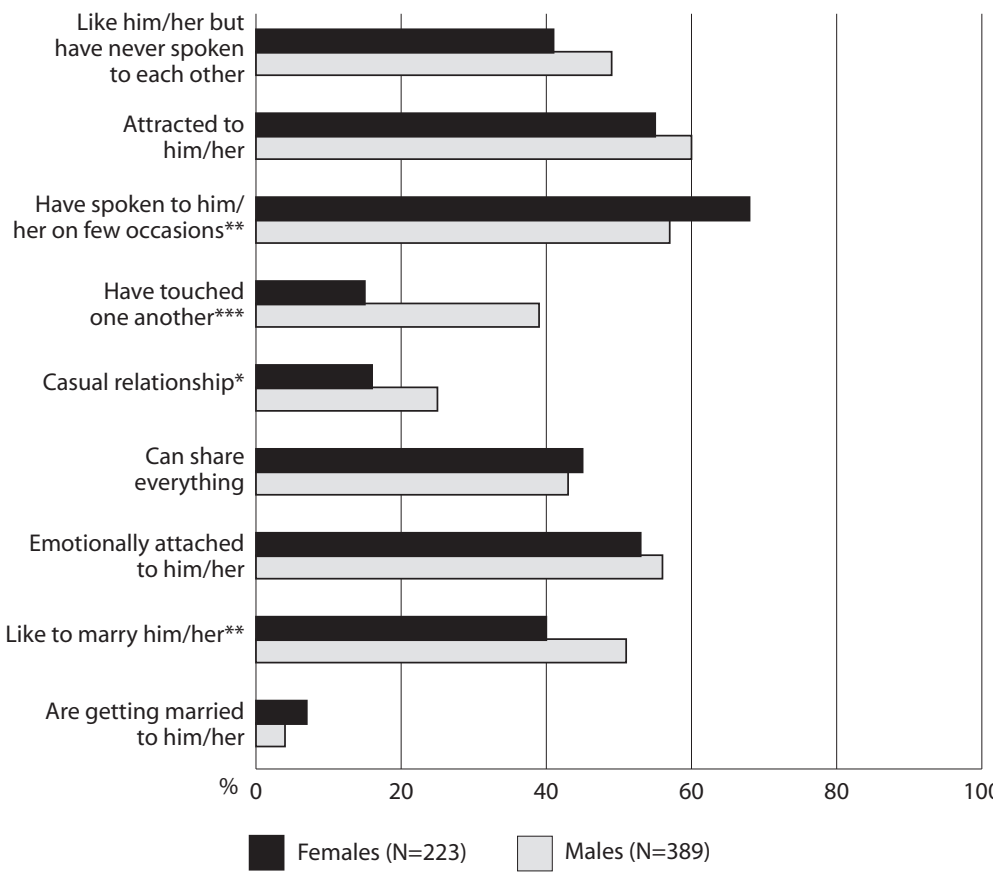

${ }^{*}$ Gender differences are significant at $\mathrm{p}<.05 .{ }^{* *}$ Gender differences are significant at $\mathrm{p}<.01 .{ }^{* * *}$ Gender differences are significant at $\mathrm{p}<.001$. Note: Multiple responses were allowed.

males may get involved in a sexual relationship to prove their love (38\% vs. $65 \%$ ) and that it is okay to have a sexual relationship if reliable contraceptives are used to prevent pregnancy (26\% vs. 51\%). Comparisons by age of the respondents show that younger females are no more conservative than the older ones; the pattern of reporting is similar to the overall gender disaggregated findings.

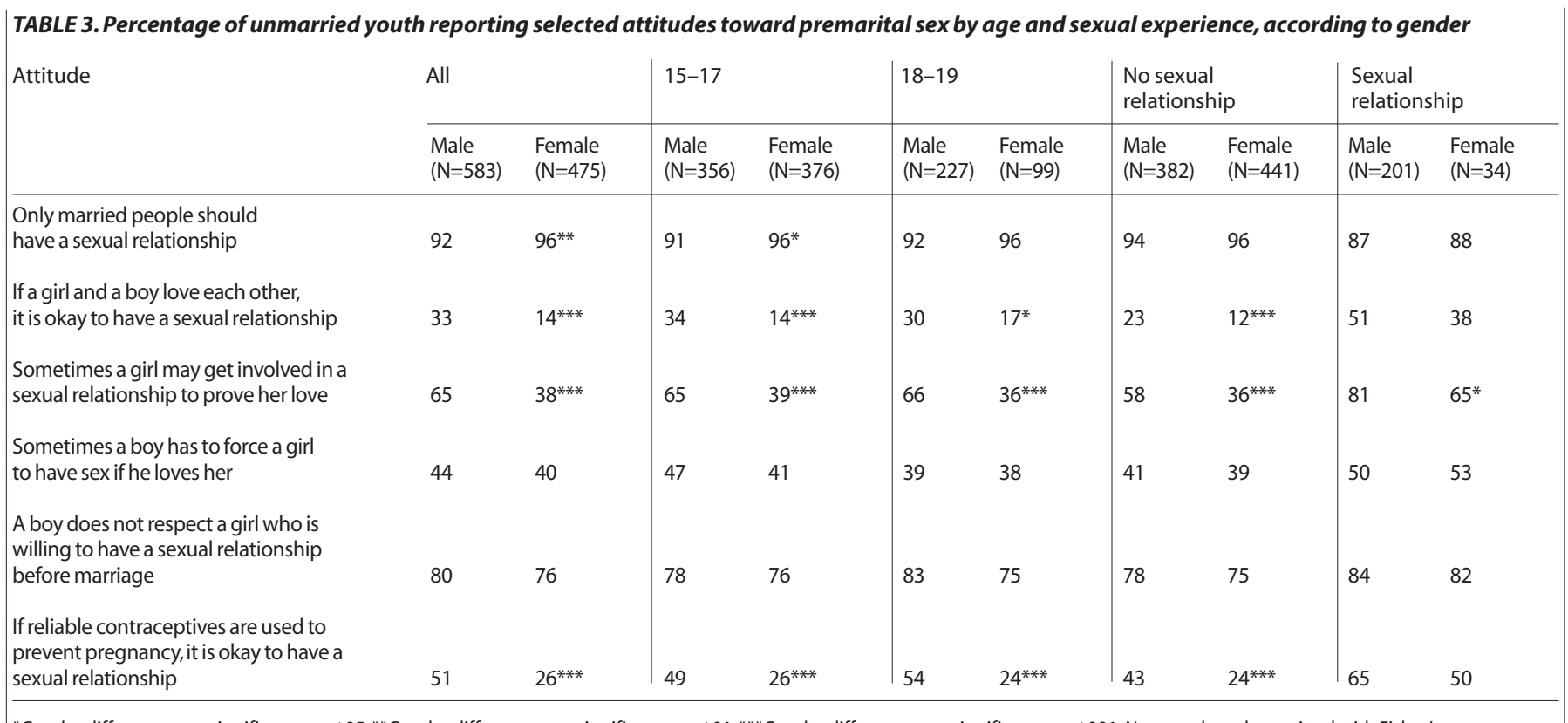

*Gender differences are significant at $\mathrm{p} \leq .05 .{ }^{* *}$ Gender differences are significant at $\mathrm{p} \leq .01 .{ }^{* * *}$ Gender differences are significant at $\mathrm{p} \leq .001$. Note: $p$ values determined with Fisher's exact test. 
When comparing attitudes by experiences of sexual relationships, we see few gender differences. Only one item remains statistically significant for those who had had sex- $81 \%$ of males, compared with $65 \%$ of females, believed that females may get involved in a sexual relationship to prove their love.

\section{Sources of Information}

The majority of the respondents (90\% of males and females) reported that they got information on reproductive and sexual health from television and films, making those media the most common source of information on these issues (not shown). Ninety-two percent of males reported that they got information from their male friends and 60\% of females reported that they got information from their female friends, suggesting that same-sex peers are an important source of information. Books and magazines were also popular sources of information, with $64 \%$ of males and $49 \%$ of females reporting that they used these sources. In addition, $54 \%$ of males and $17 \%$ of females reported that they got information from pornographic films. Parents, particularly fathers, were not an important source of information for the study respondents.

\section{DISCUSSION}

Overall, our findings are similar to recently concluded studies that illustrate significant differences in reporting by gender, with males reporting more sexual behaviors than females. ${ }^{5,16}$ Among those who reported romantic partnerships, more females than males were negative or ambivalent about these relationships. Furthermore, males were more active than females in pursuing their interest in the opposite sex. In addition, young people have a wide variety of expectations from these romantic partnerships, from casual relationships to physical intimacy and plans to get married, with more males than females reporting that they considered these partnerships a casual relationship.

Although sexual behaviors were better understood in the context of marriage until recently, especially for females, ${ }^{24}$ only $40 \%$ of females and $51 \%$ of males reported that they would like to marry their romantic partner. There could be several possible explanations, including lack of parental approval, being too young to plan marriage and also that young people today do not necessarily view premarital romantic partnerships as leading to marriage.

Among the sexually inexperienced, a larger proportion of females reported interacting with the opposite sex, whereas males more often reported having a friend of the opposite sex. These findings suggest that although there are opportunities for social mixing between the two sexes, females are hesitant to make friends with members of the opposite sex or acknowledge these friendships. In addition, these findings suggest that social norms for premarital romantic partnerships are stricter for females than males. However, the results also illustrate that despite the social restrictions and discriminatory gender norms that systematically place young women at a disadvantage, ${ }^{18}$ a substantial proportion of young people are exploring premarital heterosexual relationships.

The large majority of the respondents, including those who reported a premarital sexual relationship, reported that only married couples should have a sexual relationship, with females reporting significantly more conservative attitudes toward premarital sex than males. However, the gender differences in attitudes disappeared among those who had engaged in a sexual relationship, suggesting that in comparison with gender and age, sexual experience is a more defining characteristic for attitudes and behaviors related to premarital romantic relationships. Within this social context, a substantial proportion of young people expressed more favorable attitudes toward premarital sex under specific conditions, such as when the female and male love one another or when a reliable contraceptive method is available.

Our findings on sources of sexual and reproductive health information are in keeping with evidence from other recent studies ${ }^{14(p p .138-139), 25}$ showing that in the absence of reliable sources of information, youth rely on films and peers of the same sex for information. As a result, they are likely to be poorly informed or misinformed on these issues and prone to suffer from negative consequences of unsafe or unprotected sexual behaviors. In addition, despite evidence that relevant and correct information delays sexual initiation, prevents unwanted pregnancies and lowers rates of STI transmission, ${ }^{26}$ social norms discourage discussion of issues related to sexuality in family settings, ${ }^{19}$ as parents often believe that this would imply approval of sexual activity. ${ }^{4}$ Lack of communication with parents and trusted adults keeps young people illinformed and unlikely to receive parental support or counsel in relation to sexual matters. ${ }^{14(p p . ~ 90-91), 12 ~ S e x ~ e d u c a t i o n ~}$ remains inadequate and irrelevant to young people's needs, and reproductive health services remain inaccessible, unaffordable and of low quality. ${ }^{12}$

Our study has some limitations. For example, information on the youth's preferred source of information would have been valuable for program planners. Also, parents, teachers and opinion leaders are important adults in the lives of adolescents, and including them in the study would have provided a more comprehensive understanding of premarital romantic partnerships. An in-depth qualitative follow-up on some of the findings from this study would be an important avenue for future research. In addition, our findings may have limited generalizability to unmarried youth living in economically disadvantaged neighborhoods in larger cities in India. However, this is an important group to study because of their limited access to reliable sources of information on reproductive and sexual health and their likelihood of engaging in high-risk behaviors.

An important strength of this study lies in exploring the premarital romantic partnerships of young people, including their sexual behaviors, from their perspective; this information is extremely valuable in addressing their 
sexual and reproductive health needs. In addition, few community-based studies in India have recruited both males and females; ${ }^{12,24}$ data from both young men and women provide a comprehensive understanding of issues related to youth sexuality that can be utilized in designing effective policies and programs. Gender disparities in premarital romantic partnership formation and the experience of sexual relations argue against generic programming and demonstrate a need for sexuality education programs tailored to the different experiences and circumstances of young men and women. ${ }^{5}$

\section{REFERENCES}

1. Brown AD et al., Sexual relations among young people in developing countries: evidence from WHO case studies, Occasional Paper, Geneva: World Health Organization (WHO), Department of Reproductive Health and Research, 2001, No. 4.

2. Blum RW and Mmari KN, Risk and protective factors affecting adolescent reproductive health in developing countries, Geneva: WHO, Department of Child and Adolescent Health and Development, 2005.

3. Wellings K et al., Sexual behavior in context: a global perspective, Lancet, 2006, 368(9548):1706-1728.

4. Alexander $\mathrm{M}$ et al., Romance and sex: premarital partnership formation among young women and men, Pune district, India, Reproductive Health Matters, 2006, 14(28):144-155.

5. Alexander $\mathrm{M}$ et al., Correlates of premarital relationships among unmarried youth in Pune district, Maharashtra, India, International Family Planning Perspectives, 2007, 33(4):150-159.

6. Sodhi G, Verma M and Pelto PJ, Seeking gratification: a study of sexual behaviour patterns of adolescents in an urban slum, in: Koenig MA et al., eds., Reproductive Health in India: New Evidence, Jaipur, India: Rawat Publications, 2008, pp. 303-322.

7. Mehra S, Savithri R and Coutinho L, Sexual behaviour among unmarried adolescents in Delhi, India: opportunities despite parental controls, paper presented at the International Union for the Scientific Study of Population Regional Population Conference, Bangkok, June 10-13, 2002

8. Pachauri S and Santhya KG, Contraceptive behaviours of adolescents in Asia: issues and challenges, in: Bott $\mathrm{S}$ et al., eds., Towards Adulthood: Exploring the Sexual and Reproductive Health of Adolescents in South Asia, Geneva: WHO, 2003, pp. 108-113.

9. Bhugra D et al., Sexual attitudes and practices in north India: a qualitative study, Sexual and Relationship Therapy, 2007, 22(1):83-90.

10. Abraham L, Bhai-behen, true love, time pass: friendships and sexual partnerships among youth in an Indian metropolis, in: Koenig MA et al., eds., Reproductive Health in India: New Evidence, Jaipur, India: Rawat Press, 2008, pp. 47-64.

11. Verma RK et al., Challenging and changing gender attitudes among young men in Mumbai, India, Reproductive Health Matters, 2006, 14(28):135-143

12. Jejeebhoy SJ and Sebastian MP, Actions that protect: promoting sexual and reproductive health choices among young people in India, South and East Asia Regional Working Papers, New Delhi, India: Population Council, 2003, No. 18.

13. Sharma V and Sharma A, Adolescent boys in Gujarat, India: their sexual behavior and their knowledge of acquired immunodeficiency syndrome and other sexually transmitted diseases, Journal of Developmental and Behavioral Pediatrics, 1997, 18(6):399-404.

14. International Institute for Population Sciences (IIPS) and Population Council, Youth in India: Situation and Needs 2006-2007, Maharashtra, Mumbai: IIPS, 2008.

15. IIPS and Macro International, National Family Health Survey (NFHS-3), 2005-2006, India: Volume I, Mumbai: IIPS and Macro International, 2007.
16. Shekhar M, Ghosh S and Panda P, Exploring safe sex awareness and sexual experiences of adolescents in Patna, Economical and Political Weekly, 2007, 42(48):48-55

17. Jejeebhoy SJ and Sebastian MP, Young people's sexual and reproductive health, in: Jejeebhoy SJ, ed., Looking Back, Looking Forward: A Profile of Sexual and Reproductive Health in India, New Delhi: Population Council, and Jaipur, India: Rawat Publications, 2004, pp. 138-168.

18. Weiss E, Whelan D and Gupta GR, Vulnerability and Opportunity: Adolescents and HIV/AIDS in the Developing World, Washington, DC: International Council for Research on Women, 1996.

19. Lakshmi PV, Gupta N and Kumar R, Psychosocial predictors of adolescent sexual behavior, Indian Journal of Pediatrics, 2007. 74(10):923-926.

20. Pachauri S and Santhya KG, Reproductive choices for Asian adolescents: a focus on contraceptive behavior, International Family Planning Perspectives, 2002, 28(4):186-195.

21. WHO, Adolescent health, Fact Sheet, New Delhi: WHO, Regional Office for South-East Asia, 2007.

22. National AIDS Control Organisation, Youth and HIV/AIDS, 2007, $<$ http://www.nacoonline.org/Quick_Links/Youth>, accessed Oct. 29, 2008.

23. Altman DG, Practical Statistics for Medical Research, Boca Raton, FL, USA: Chapman \& Hall/CRC, 1991, pp. 253-257.

24. Jejeebhoy SJ, Adolescent sexual and reproductive behavior: a review of the evidence from India, Social Science \& Medicine, 1998, 46(10):1275-1290.

25. McManus A and Dhar L, Study of knowledge, perception and attitude of adolescent girls towards STIs/HIV, safer sex and sex education: a cross-sectional survey of urban adolescent school girls in south Delhi, India, BMC Women's Health, 2008, Vol. 8, Art. 12, <http://www. biomedcentral.com/1472-6874/8/12>, accessed Mar. 16, 2009.

26. UNAIDS Inter-Agency Task Team on Young People, At the Crossroads: Accelerating Youth Access to HIV/AIDS Interventions, 2004, $<$ http://www.unfpa.org/upload/lib_pub_file?316_filename_UNFPA_ Crossroads.pdf>, accessed Sept. 18, 2006.

\section{RESUMEN}

Contexto: A pesar de las normas sociales restrictivas, hay pruebas crecientes de que la gente joven en India tienen relaciones románticas y sexuales premaritales. Sin embargo, la información sobre la forma en que inician y construyen estas relaciones es escasa, aun cuando es vital para abordar las necesidades de la gente joven.

Métodos: Las actitudes hacia las relaciones románticas y la conducta dentro de ellas se examinaron usando datos recolectados en 2004, de jóvenes solteros (583 hombres y 475 mujeres, de 15-19 años de edad), que viven en vecindarios en desventaja económica en Delhi, India. Las asociaciones entre las actitudes o conductas específicas y la edad, género y experiencia sexual, se determinaron utilizando pruebas exactas de Fisher.

Resultados: Sesenta y dos por ciento de los hombres y $53 \%$ de las mujeres reportaron que alguien del sexo opuesto habia expresado interés en ellos; 86\% de los hombres y 63\% de las mujeres reportaron sentirse bien por ello. Adicionalmente, $67 \%$ de los hombres y $47 \%$ de las mujeres reportaron que les gustaba alguien del sexo opuesto. Comparados con las mujeres, los hombres tuvieron mayor probabilidad de buscar información sobre la persona en la que estaban interesados (76\% vs. $61 \%)$; y de tener relaciones sexuales premaritales heterosexuales (32\% vs. 6\%). Las mujeres tuvieron menor probabili- 
dad de responder que es apropiado mantener relaciones sexuales premaritales si el hombre y la mujer se aman que los hombres (14\% vs. 33\%). Tanto para los hombres como para las mujeres, la televisión y los filmes fueron la fuente más popular de información sobre temas relacionados con la salud sexual. Conclusiones: Las disparidades de género en la formación de relaciones románticas premaritales y la experiencia de relaciones sexuales, son sólidos argumentos a favor de los programas de educación en sexualidad diseñados para las diferentes experiencias y circunstancias de las mujeres y hombres jóvenes.

\section{RESUMEN}

Contexto: A pesar de las normas sociales restrictivas, hay pruebas crecientes de que la gente joven en India tienen relaciones románticas y sexuales premaritales. Sin embargo, la información sobre la forma en que inician y construyen estas relaciones es escasa, aun cuando es vital para abordar las necesidades de la gente joven.

Métodos: Las actitudes hacia las relaciones románticas y la conducta dentro de ellas se examinaron usando datos recolectados en 2004, de jóvenes solteros (583 hombres y 475 mujeres, de 15-19 años de edad), que viven en vecindarios en desventaja económica en Delhi, India. Las asociaciones entre las actitudes o conductas específicas y la edad, género y experiencia sexual, se determinaron utilizando pruebas exactas de Fisher. Resultados: Sesenta y dos por ciento de los hombres y $53 \%$ de las mujeres reportaron que alguien del sexo opuesto había expresado interés en ellos; $86 \%$ de los hombres y $63 \%$ de las mujeres reportaron sentirse bien por ello. Adicionalmente, 67\% de los hombres y $47 \%$ de las mujeres reportaron que les gustaba alguien del sexo opuesto. Comparados con las mujeres, los hombres tuvieron mayor probabilidad de buscar información sobre la persona en la que estaban interesados (76\% vs. 61\%); $y$ de tener relaciones sexuales premaritales heterosexuales (32\% vs. 6\%). Las mujeres tuvieron menor probabilidad de responder que es apropiado mantener relaciones sexuales premaritales si el hombre y la mujer se aman que los hombres ( $14 \%$ vs. $33 \%$ ). Tanto para los hombres como para las mujeres, la televisión y los filmes fueron la fuente más popular de información sobre temas relacionados con la salud sexual.

Conclusiones: Las disparidades de género en la formación de relaciones románticas premaritales y la experiencia de relaciones sexuales, son sólidos argumentos a favor de los programas de educación en sexualidad diseñados para las diferentes experiencias y circunstancias de las mujeres y hombres jóvenes.

\section{RÉSUMÉ}

Contexte: En dépit de normes sociales restrictives en Inde, il est de plus en plus clair que les jeunes s'y engagent, avant le mariage, dans des relations de nature romantique et sexuelle. La manière dont ils établissent ces relations n'est guère documentée. Cette information est cependant essentielle si l'on veut répondre aux besoins des jeunes.

Méthodes: Les attitudes et les comportements à l'égard et au sein des relations romantiques ont été examinés sur la base de données recueillies en 2004 auprès de jeunes célibataires (583 jeunes hommes et 475 jeunes femmes de 15 à 19 ans) vivant dans les quartiers économiquement défavorisés de Delhi, en Inde. Les associations entre certains comportements ou attitudes spécifiques et l'âge, le sexe et l'expérience sexuelle ont été déterminées par tests de Fisher.

Résultats: Soixante-deux pour cent des garçons et 53\% des filles ont déclaré qu'une personne de sexe opposé avait exprimé un intérêt à leur égard; $86 \%$ des garçons et 63\% des filles ont dit en avoir apprécié le sentiment. De plus, 67\% des garçons et $47 \%$ des filles ont déclaré qu'une personne de sexe opposé leur plaisait. Par rapport aux filles, les garçons sont plus susceptibles de s'informer sur la personne qui les intéresse (76\% par rapport à 61\%) et de s'engager dans des relations hétérosexuelles antérieures au mariage (32\% par rapport à 6\%). Les filles sont moins susceptibles que les garçons de se déclarer favorables aux rapports sexuels antérieurs au mariage si le couple s'aime (14\% par rapport à $33 \%$ ). Pour les deux sexes, la télévision et les films sont les sources d'information les plus courantes sur les questions relatives à la santé sexuelle.

Conclusions: Les divergences entre les filles et les garçons concernant l'établissement de relations romantiques prénuptiales et l'expérience de relations sexuelles justifient clairement le besoin de programmes d'éducation à la sexualité adaptés aux différentes expériences et circonstances des deux sexes.

\section{Acknowledgments}

This study was conducted by Jaya as part of her dissertation research for the degree of doctorate in public health. The study was funded by a Mellon grant to the Johns Hopkins University Population Center, a dissertation grant from the Bill and Melinda Gates Institute of Population and Reproductive Health, and the Woodrow Wilson-Johnson E Johnson Dissertation Fellowship in Women's Health. The opinions expressed in this paper are solely those of the authors and do not necessarily reflect the views of the United Nations Population Fund or the United Nations.

Author contact:jjayal@jhsph.edu 